\title{
Spadek cen ropy naftowej w gospodarce światowej - główne przyczyny i konsekwencje. Analiza na przykładzie okresu 2014/2015
}

\section{The plunge of Oil Prices in the Global Economy - Main Determinants and Implications. Analysis on the Basis of the Period of 2014-2015}

\begin{abstract}
Synopsis. Celem artykułu jest analiza determinant i konsekwencji spadku cen ropy naftowej w okresie 2014/2015. Epizody te są słabiej opisane w literaturze przedmiotu, w porównaniu do okresów wzrostu, zarówno na gruncie badań teoretycznych, jak i empirycznych. Wynika to z mniejszej częstotliwości występowania okresów spadku cen, jak i oczekiwanych $\mathrm{w}$ mniejszym stopniu negatywnych konsekwencji. Doświadczenia lat 2014/2015 wykazują że także okres spadku cen surowca ma negatywne konsekwencje, przede wszystkim dla eksporterów, ale także dla importerów oraz gospodarki globalnej. W artykule wykorzystano zasadniczo dwa obszerne raporty międzynarodowych instytucji: Banku Światowego i Międzynarodowego Funduszu Walutowego oraz dokonano przeglądu literatury światowej. Zwrócono uwagę na dylematy krajów eksporterów z wyborem odpowiedniej polityki dostosowawczej, w tym rolę polityki fiskalnej i kursowej, oraz reformy strukturalne w zarządzaniu powstałą nierównowagą zewnętrzną i fiskalną tej grupy krajów.
\end{abstract}

Słowa kluczowe: szoki naftowe, polityka dostosowawcza, równowaga zewnętrzna

\begin{abstract}
The aim of the article is to investigate the main determinants and implications of the fall of oil prices during the period of 2014/2015. The episodes of oil prices' plunge are not presented in the literature, both theoretical and empirical one, as much as the episodes of price increases. The episodes of plunge are not as common in the economy as episodes of increases, and the negative consequences of the former are supposed not to be as severe as these of the latter. On the basis of the experiences of the last oil price plunge one can see the negative consequences can tackle both exporters and importers. The article is based mainly on two broad reports, of IMF and World Bank, and a set of publications. It discusses the problems of adjustment policy, especially fiscal and exchange rate policies, and structural reforms taken by exporting countries in the process of management of external and fiscal imbalances.
\end{abstract}

Key words: oil shocks, adjustment policy, external balance

JEL Classification: F32, F62

\section{Wprowadzenie}

Od czasu komercyjnej produkcji ropy naftowej (datowanej na 1859 r., w Pensylwanii), cechą charakterystyczną rynku ropy naftowej była w miarę duża stabilność jej cen. Zmienność cen ropy objawiająca się epizodami gwałtownych jej spadków i wzrostu (boom

\footnotetext{
${ }^{1}$ dr hab., prof. UŁ, Instytut Gospodarki Międzynarodowej UŁ, ul. POW 3/5, 90-255 Łódź,
} e-mail: joannabogolebska@wp.pl; https://orcid.org/0000-0002-9150-150X 
and bust episodes) stała się cechą tego rynku surowcowego od końca lat $70 \mathrm{XX}$ w. W okresie 1946-2016 realne ceny ropy (cena gatunku WTI, w cenach USD z 2015 r.) fluktuowały od 145 USD za baryłkę do 15 USD (Mohaddes, 2017). Szeroka literatura teoretyczna i empiryczna dotyczy głównie okresów wzrostu cen surowca (szoki naftowe z lat 70, szok naftowy z 2007/2009 r.), ich przyczyn i konsekwencji. Prezentowany artykuł koncentruje się na okresach spadku cen ropy, zaś rozważania dotyczą zarówno gospodarek narodowych (ze szczególnym uwzględnieniem krajów eksportujących, w tym wiodących trzech producentów: Arabii Saudyjskiej, Rosji i USA), jak i gospodarki globalnej. Artykuł ma charakter przeglądu literatury światowej dotyczącej determinant spadku cen w 2014/2015 r. oraz ich konsekwencji. Identyfikacja przyczyn spadku cen ropy ma kluczowe znaczenie dla oszacowania prawdopodobnego wpływu na gospodarki krajowe oraz gospodarkę globalną. Tradycyjnie w literaturze wyrażany jest pogląd, że implikacje wahań cen ropy dla gospodarek narodowych i gospodarki globalnej w dużej mierze zależą od czynnika (popytowy versus podażowy) odpowiadającego za powstały szok cenowy, oraz specyficznych uwarunkowań danego kraju. Dlatego też brak jest jednoznacznych wskazań w literaturze, jak powinna wygląać optymalna polityka gospodarcza w odpowiedzi na powstały szok cenowy, reakcja ta wciąż budzi kontrowersje i jest przedmiotem ożywionych dyskusji.

Celem artykułu jest także zaakcentowanie dokonującego się w pewnym stopniu przeorientowania poglądu dotyczącego konsekwencji spadku cen surowca. W literaturze przedmiotu dotychczas podkreślano, że ze spadku cen ropy korzystają importerzy, zaś eksporterzy traca. Tymczasem spadek cen ropy z 2014/2015 r. poddał w wątpliwość wyrażany pogląd, że niższe ceny ropy, stymulując wzrost gospodarczy, są jednoznacznie korzystne dla importerów i gospodarki globalnej.

\section{Epizody spadku cen ropy w gospodarce globalnej}

Epizody spadku cen ropy były dotychczas słabiej opisane w literaturze w porównaniu do okresów wzrostu. Wynika to z faktu, że okresów spadku cen było mniej w porównaniu do wzrostu, które to przez wzrost kosztów produkcji wywoływały naciski inflacyjne w gospodarce globalnej i prowadzily do spadku efektywnego popytu.

MFW wskazuje, że w ostatnich dekadach były 3 znaczące epizody spadku cen (2014/15, 2008/9 oraz 1985/6). Z kolei w swoim Raporcie Bank Światowy argumentuje, że spadek cen ropy odnotowany $\mathrm{w}$ drugiej połowie $2014 \mathrm{r}$. należy do jednego $\mathrm{z}$ pięciu epizodów największego spadku cen w okresie ostatnich trzech dekad. Epizody te wyodrębnione są ze względu na 30-procentowy lub większy spadek cen ropy w okresie 7 miesięcy. Bank Światowy zwraca szczególną uwagę na epizod z lat 1985-86 r. Jego wiodącą determinantą była istotna zmiana w polityce OPEC - członkowie OPEC postanowili zwiększyć produkcję, pomimo wzrostu podaży ze źródeł niekonwencjonalnych, aby w ten sposób zwiększyć swój udział w rynku (IMF, 2015). Z tego też powodu - czynnika podażowego jako wiodącej determinanty szoku cenowego - epizod z 2014 r. jest najczęściej właśnie porównywany do tego z lat 1985/86. Nie podlega dyskusji, że oba nastapily po szybkim wzroście niekonwencjonalnych źródeł podaży ze strony krajów nienależących do OPEC oraz zmianie polityki OPEC. Ponadto, oba szoki charakteryzowało to, że wzrost PKB pozostawał na $\mathrm{w}$ miarę stabilnym poziomie $\mathrm{w}$ pierwszym roku spadku cen. $\mathrm{W}$ obu epizodach $\mathrm{w}$ pierwszym roku spadku cen wystąiły podobne prawidłowości: nie było widocznego przyspieszenia 
aktywności gospodarczej, ponadto miesięczna produkcja przemysłowa utrzymywała się na podobnym poziomie (Husain, 2015).

Pozostałe epizody były zasadniczo powodowane słabnącym popytem globalnym wynikającym z: recesji w USA (lata 1990-1991), kryzysu azjatyckiego (1997-98), wydarzeniami 11 września (2001), globalnym kryzysem finansowym (2008-2009).

Większość poprzednich epizodów spadku cen ropy charakteryzowało to, że poprzedzało je znaczne spowolnienie wzrostu gospodarczego (mające swoje odzwierciedlenie w spadku cen) i powolne ożywienie w jego następstwie, przekładające się na słaby wzrost, zarówno w krajach rozwiniętych, jak i rozwijających się. Dodatkowo charakteryzowała je niższa inflacja i znaczne zwiększenie stopnia akomodacyjnej polityki pieniężnej w USA i innych wiodących krajów rozwiniętych. Doświadczenia spadku cen z roku 1986 wskazują na nieefektywność polityki pieniężnej w ożywianiu wzrostu gospodarczego. Seria obniżek stóp procentowych Systemu Rezerwy Federalnej, mająca na celu stymulowanie koniunktury i przeciwdziałanie spadającej inflacji, okazała się nieskuteczna. Czynnikami utrudniającymi efektywną politykę gospodarczą były problemy zadłużeniowe dużych krajów rozwijających się, słaby wzrost gospodarczy w Japonii i wielu krajach europejskich, znaczne spadki na amerykańskich i globalnych giełdach kapitałowych.

\section{Determinanty spadku cen ropy w okresie 2014/2015}

$\mathrm{Na}$ sektor energetyczny, a w szczególności ropy naftowej, oddziałują czynniki podażowo-popytowe oraz oczekiwania rynku odnośnie kształtowania się przyszłych warunków (ze względu na dużą skalę oparcia sektora na kontraktach futures). Spadek cen ropy o około 50\%, z 114 USD w czerwcu 2014 do 46 USD w styczniu 2015, który zakończył kilkuletni okres stabilności cenowej, wywołał obszerną dyskusję dotyczącą jego determinant i implikacji. W literaturze panuje consensus, że spadek ten wywołały zarówno czynniki o charakterze długookresowym (podażowo-popytowe), jak i krótkookresowym (nastroje rynkowe, prognozy gospodarcze, kurs USD). Wkład poszczególnych czynników jest jednak trudny do skwantyfikowania. Szacunki pokazują, że czynniki podażowe odpowiadają za $30 \%$, popytowe za 20\%, kurs USD 0-3\%, inne czynniki za pozostałą część spadku cen ropy (Baffes, 2015).

W analizie przyczyn spadku cen ropy w 2014 r. w literaturze dominują poglądy wskazujące na większą rolę determinant podażowych (nadmierna podaż) w stosunku do czynników popytowych. Pogląd taki wyraża w swoim raporcie Bank Światowy, który wykazuje na podstawie metod ekonometrycznych, że czynniki podażowe odegrały dwukrotnie większą rolę od czynników popytowych (World Bank, 2015). Ograniczeniem zastosowania tych metod, zdaniem MFW, jest to, że nie uwzględniają one roli zmian w oczekiwaniach oraz zachowaniach strategicznych, w tym OPEC (Husain, 2015).

Dla przykładu, M. Khan za główny czynnik spadku cen ropy uznaje wzrost krajowej produkcji surowca w USA i Iraku. Zwraca uwagę, że krajowa produkcja ropy wzrosła w USA z 5,6 mln baryłek dziennie w 2006 r. do 9,4 mln baryłek w 2017 r., wypierając import ropy i zmuszając tradycyjnych producentów do poszukiwania alternatywnych rynków i obniżania cen. Równie istotne znaczenie miał wzrost inwestycji w odnawialne źródła energii w takich krajach jak Chiny i USA, które tradycyjnie należały do największych konsumentów ropy. (Khan, 2017). 
Jak wskazuje Bank Światowy, ekspansja podaży ropy ze źródeł niekonwencjonalnych (głównie w USA) oraz zmiana polityki OPEC polegająca na wsparciu cen odgrywały wiodaccą rolę w spadku cen surowca. Zmiana polityki OPEC ogłoszona w listopadzie 2014 r., polegająca na nieobniżaniu produkcji ropy, mimo wzrostu produkcji ze strony krajów nienależących do OPEC, czyli utrzymaniu udziału grupy w rynku oznacza, zdaniem wielu analityków, że nie będzie ona już odgrywała roli tzw. ostatniego dostawcy (swing producer). Zatem od strony podażowej zwraca się uwagę na dwa źródła szoku cenowego: rosnącą produkcję ze strony krajów nienależących do OPEC, oraz wyższą niż się spodziewano podaż ze strony krajów OPEC (głównie Arabia Saudyjska, Irak, Libia), która fundamentalnie zmieniła oczekiwania odnośnie przyszłej podaży ze strony tej organizacji (Behar, 2017).

Do innych trzech wiodących czynników spadku cen w Raporcie Banku Światowego zalicza się: słabnący popyt globalny, ryzyka geopolityczne oraz aprecjację USD. Od strony popytowej zwraca się uwage na słabszy od oczekiwanego wzrost gospodarczy i popyt ze strony Azji (głównie Chin) i Europy, redukujący obecną i spodziewaną konsumpcję surowca.

Wśród czynników geopolitycznych mogących przyczyniać się do niestabilności na rynku ropy, zwraca się uwagę na konflikty na Bliskim Wschodzie (Libia, Irak, Syria), napięte stosunki międzynarodowe z Iranem, sankcje gospodarcze nałożone na Rosję.

Ze względu na to, że USD pełni funkcję jednostki rozliczeniowej w światowym obrocie ropa, jego aprecjacja powinna działać ograniczająco na wzrost cen surowca. Badania empiryczne nad zakresem wpływu aprecjacji USD na cenę ropy różnią się - w ujęciu skrajnym wykazują, że $10 \%$ aprecjacja przenosi się na nawet na 10-procentowy spadek cen, według innych na 3\%. Rolę kursu walutowego w determinowaniu ceny ropy podkreśla C.Donahue, który wykazuje, że silniejszy USD, w połączeniu ze słabnąca gospodarką globalną, był wiodącą przyczyną spadku cen. (Donahue, 2016). Z kolei D.Tokic wskazuje, że za spadkiem cen ropy stoi w dużej mierze irracjonalnie nadmierna reakcja na spadający kurs euro wobec USD. (Tokic, 2015). Warto jeszcze w tym miejscu przytoczyć argument C.Baumeister i in., którzy dowodzą, że $-\mathrm{z}$ uwagi na to, że zarówno cena ropy, jak i kurs USD zależą od kształtowania się gospodarki globalnej- nie można stwierdzić że zmiany kursu USD wywierają niezależny wpływ na ceny surowca. (Baumeister, 2015).

Zdaniem C.Baumeister i in., spadek cen z 2014 r. odzwierciedla także skumulowane efekty wcześniejszych szoków podażowych i popytowych. (Baumeister, 2015). Podkreśla się także, że epizod ten charakteryzuje się tym, że spadek cen wynika raczej $\mathrm{z}$ oczekiwanych, aniżeli aktualnych uwarunkowań popytowo-podażowych. Rolę oczekiwań podkreśla także D.Fantazzini, dowodząc że w okresie 2014/2015 pojawił się negatywny bąbel, który obniżał ceny ropy poniżej wartości wynikających $\mathrm{z}$ fundamentów ekonomicznych. Jak thumaczy D.Fantazzini, negatywny bąbel finansowy jest sytuacją, w której narastający pesymizm, wynikający ze wzrostu krótkich pozycji, powoduje, że inwestorzy uciekają z rynku, co staje się samospełniającą się prognozą. (Fantazzini, 2016).

Jak wskazuje MFW, brak jest oczywistych dowodów empirycznych, że spekulacja i finansjalizacja mogą być motorem spadku cen, mimo że nie ulega wątpliwościom, że wahania cenowe są wzmacniane poprzez zmiany finansowych nastrojów inwestorów (IMF, 2015). 


\section{Makroekonomiczne i finansowe konsekwencje spadku cen ropy naftowej}

Ropa naftowa jest strategicznym surowcem energetycznym, wpływającym na warunki funkcjonowania wszystkich gałęzi przemysłu. Silne uzależnienie od ropy powoduje, że zmiany jej cen wpływają zarówno na kraje eksportujące, jak i importujące, oraz gospodarkę globalną.

Wśród globalnych konsekwencji spadku cen ropy tradycyjnie zwraca się uwagę na: efekt przesunięcia realnych dochodów od eksporterów w kierunku importerów, wzrost globalnego PKB oraz spadek globalnej inflacji. Podkreśla się, że zmiany w globalnej produkcji i przesunięcia $\mathrm{w}$ dochodach między eksporterami a importerami występują, kiedy ruchy cen wynikają z szoków podażowych. Wskazuje się, że zmiany te mają znacznie słabszy charakter, jeśli są powodowane szokami popytowymi. Ponadto, widoczna jest tu asymetria - spadki cen ropy dają słabszy efekt produkcyjny dla importerów ropy, niż wzrost cen. Asymetria ta może wynikać z niepewności i różnej reakcji polityki pieniężnej na odmienne kierunki wahań cen. (Jimenez-Rodriguez, 2005).

Według Banku Światowego, wynikający z podaży spadek cen ropy o $45 \%$ powinien przełożyć się na wzrost globalnego PKB o $0,7-0,8 \%$ w średnim okresie oraz spadek globalnej inflacji o około 1 punkt procentowy w krótkim okresie. (World Bank, 2015).

Ożywienie gospodarcze $\mathrm{w}$ krajach importerach ropy wynika ze wzrostu realnych dochodów gospodarstw domowych i przedsiębiorstw w warunkach spadku cen. Efekt ten powinien działać na zasadzie podobnej do cięć podatkowych. Wzrost dochodów realnych, prowadząc do wzrostu wydatków, powinien wspierać wzrost globalny. Zatem, kanał popytowy powinien odgrywać kluczową rolę $\mathrm{w}$ transmisji szoku cenowego. Ponadto, należy podkreślić, że podczas gdy pozytywny dla importerów efekt spadku cen wymaga czasu, aby mógł się zmaterializować, negatywny wpływ na eksporterów ma charakter natychmiastowy, często wzmacniany przez działanie rynków finansowych. Doświadczenia wykazują ponadto, że wpływ cen surowca na aktywność gospodarczą słabnie od połowy lat 80, co tłumaczy się spadającą rolą ropy w kreowaniu PKB, wzrastającą elastycznością rynków pracy i lepiej zakotwiczonymi oczekiwaniami inflacyjnymi. (World Bank, 2015). $\mathrm{O}$ ile zatem, teoretycznie, spadek cen ropy powinien pozytywnie przekładać się na gospodarki krajów importerów, w praktyce ostatni epizod spadku cen miał niższe od oczekiwanych przełożenie na globalny wzrost. Z badań wynika, że spadek o $10 \%$ cen ropy może stymulować wzrost gospodarczy o $0,1-0,5 \%$, w zależności od udziału importu ropy w PKB kraju. (Tang, 2010). Jak wskazuje MFW, pro wzrostowy efekt spadku cen ropy w niektórych krajach importerach był złagodzony poprzez deprecjację kursu walutowego. (IMF, 2015).

Wskazuje się, że spodziewanym korzyściom w postaci wyższego wzrostu i niższej inflacji mogą przeciwdziałać takie czynniki jak: słabszy popyt globalny, czy ograniczone pole dla dodatkowego łagodzenia monetarnego w wybranych krajach. Dla przykładu, M.Obstfeld dowodzi, że środowisko „bliskich zeru stóp procentowych” występujące w większości krajów uprzemysłowionych oraz fakt, że USA zaczęły ponownie eksportować ropę, spowodowały zmianę tradycyjnych kanałów, przez które niższe ceny ropy przenoszą się na gospodarkę realną. (Obstfeld, 2016). Ponadto, wykazuje się, że dodatnia korelacja między cenami ropy a rynkami akcji w ostatnich latach jest dowodem na spowolnienie globalnej aktywności gospodarczej, gdyż spadek globalnego zagregowanego 
popytu obniżył zyski przedsiębiorstw i popyt na ropę. (Bernanke, 2016). Jak zatem podkreśla K.Mohaddes i in., epizod spadku cen ropy z 2014 r. nie jest korzystny dla USA, tym samym obniżając też korzyści dla innych uprzemysłowionych krajów i gospodarki globalnej. K.Mohaddes i in. wykazują empirycznie, że spadek cen ropy obniża stopy procentowe i inflację $\mathrm{w}$ większości krajów, jednocześnie podnosząc globalne realne ceny akcji. Ponadto, wpływ spadku cen ropy na realna produkcję jest pozytywny, ale wymaga dłuższego czasu aby się zmaterializował. (Mohaddes, 2017).

Weryfikacja poglądu odnośnie wpływu spadku cen ropy na gospodarkę USA (które są największym konsumentem ropy na świecie) wskazuje, że korzyści są mniejsze niż tradycyjnie wskazywano. Podczas gdy niskie ceny ropy są korzystne dla konsumentów, zwiększają bowiem ich oszczędności, jednocześnie działają na niekorzyść producentów ropy, obniżając inwestycje przedsiębiorstw działających w branży energetycznej (np. związanych z poszukiwaniem nowych zasobów, bezpieczeństwem wierceń), i negatywnie wpływając na ich zyski.

Zgodnie z rozważaniami teoretycznymi, spadające ceny ropy mogą pociaggnąc spadek cen artykułów rolno-spożywczych i innych surowców. Na podstawie historycznych elastyczności Bank Światowy szacuje, że $45 \%$ spadek cen ropy obniża ceny tychże artykułów o $10 \%$. Obecne przełożenie (pass-through) cen na ceny wewnętrzne było jeszcze słabsze, $50 \%$ spadek cen ropy przełożył się jedynie na $7 \%$ spadek cen artykułów rolnych i żywności. (World Bank, 2015). Z kolei słabszy popyt i efekty substytucji spowodowały spadek cen innych źródeł energii. Słabnące przełożenie cen ropy na ceny wewnętrzne tłumaczy się zmniejszoną zależnością produkcji i konsumpcji od ropy oraz lepszym kotwiczeniem oczekiwań inflacyjnych. Dezinflacyjny impuls wywołany spadkiem cen ropy może być ponadto łagodzony poprzez gwałtowne dostosowania kursowe oraz wpływ podatków, subsydiów i regulacji na ceny. Czynniki te mogą niewątpliwie osłabiać wpływ zmian cen surowca na inflację. Z badań Banku Światowego wynika ponadto, że wśród krajów rozwiniętych, wpływ tendencji cenowych na rynku ropy na inflację mierzoną cenami konsumenta jest wyraźniejszy w przypadku Stanów Zjednoczonych niż strefy euro i Japonii, a wśród krajów rozwijających się wyraźniejszy w przypadku Indii, Indonezji, Turcji niż Chin czy Brazylii, co tłumaczy się w dużej mierze odmiennymi wzorcami konsumpcji energii, regulacji cenowych i reżimów kursowych. (World Bank, 2015).

Należy także zauważyć, że kraje rozwijające się w większym stopniu korzystają ze spadku cen surowca od krajów rozwiniętych, gdyż energia i żywność stanowi w ich przypadku większą część koszyka konsumpcyjnego. Również oczekiwania inflacyjne w krajach rozwijających się bardziej odpowiadają na zmiany cen surowca.

Kolejnym kanałem oddziaływań zmian cen ropy są pozycje fiskalne krajów. Dla przykładu, w przypadku bardzo silnie uzależnionej od eksportu ropy naftowej Arabii Saudyjskiej, wpływy z eksportu surowca stanowią 90\% dochodów budżetowych (Khan, 2017). Rekordowy deficyt budżetowy Arabii Saudyjskiej odnotowany w roku gwałtownego spadku cen surowca (2015), wyniósł 15\% PKB. W przypadku Iranu, spadek cen ropy powoduje silny niedobór dochodów budżetowych - szacuje się że dla tego kraju cena kształtująca się na poziomie co najmniej $100 \mathrm{USD} /$ baryłkę pozwala zrównoważyć budżet. (Khan, 2017). W przypadku niektórych krajów eksporterów ropy, (głównie regionu Bliskiego Wschodu oraz Afryki), wpływy związane z eksportem surowca stanowią więcej niż połowę wpływów budżetowych. (World Bank, 2015). Według analiz Bloomberga, w grudniu 2014 r., wszystkie kraje członkowskie OPEC z wyjątkiem Kataru, nie mogły liczyć na wpływy z eksportu ropy dla zrównoważenia budżetów krajowych. Z szacunków 
wynika, że większość krajów OPEC potrzebuje ceny powyżej 80 USD za baryłkę ropy, aby zrównoważyć budżet krajowy. (Khan, 2017). W przypadku tych krajów, spadające ceny ropy mogą spowodować napięcia w polityce fiskalnej, zaś pogarszające się prognozy wzrostu sprzyjać deprecjacji kursu. W niektórych krajach, napięcia wynikające ze spadku wpływów budżetowych mogą być łagodzone przez różne bufory finansowe - np. transfery środków zakumulowanych $\mathrm{w}$ ramach Państwowych Funduszy Majątkowych (Sovereign Wealth Funds) lub rezerwach walutowych. W przypadku takich krajów jak Libia, czy Jemen, które nie dysponują takimi buforami finansowymi, spadek cen ropy może oznaczać znaczne dostosowania zewnętrzne i fiskalne, w tym poprzez deprecjację kursu lub skurczenie importu.

Zmiany cen ropy mogą także przełożyć się na wzrost zmienności na rynkach finansowych, w tym walutowych, oraz wpłynąć na przepływy kapitałowe. Spowolnienie gospodarcze w krajach eksportujących ropę może spowodować pogorszenie bilansów przedsiębiorstw, a poprzez wzrost portfela złych kredytów, także banków. Premia za ryzyko kraju i inne rodzaje ryzyk może wzrosnąć, podnosząc koszt kredytu i dodatkowo osłabiając aktywność gospodarczą.

Dobrym przykładem ilustrującym wpływ wahań cen ropy na przepływy kapitałowe jest zjawisko akumulacji/dekumulacji rezerw walutowych. Kraje eksportujące ropę naftową należały (od połowy lat 90) do kluczowych uczestników procesów akumulacji rezerw w gospodarce globalnej, przyczyniając się jednocześnie do narastania tzw. nierównowag globalnych. W ciagu dekady 2005-2015, rezerwy w posiadaniu eksporterów ropy uległy pięciokrotnemu zwiększeniu, od 2004 r. stanowiąc 15\% skumulowanego wzrostu światowych zasobów rezerw (IMF, 2015). Stanowily tym samym istotne źródło finansowania globalnego systemu bankowego i rynków kapitałowych. Depozyty pochodzące $\mathrm{z}$ krajów eksportujących ropę $\mathrm{w}$ bankach raportujących $\mathrm{w}$ Banku Rozrachunków Międzynarodowych uległy podwojeniu od 2004 r., kraje te posiadaja (zarówno sektor publiczny, jak i prywatny) bardzo duży udział amerykańskich aktywów (akcji, papierów dłużnych emitowanych przez rząd i podmioty rządowe). Zawężenie nadwyżek płatniczych krajów eksporterów wynikających ze spadku wpływów z ropy doprowadziło do gwałtownego spadku poziomu akumulowanych rezerw już w $2014 \mathrm{r}$. Spadek ten był szczególnie widoczny w przypadku Arabii Saudyjskiej i Rosji (choć należy pamiętać, że w Rosji były też inne przyczyny głębokiego spadku rezerw, mianowicie sankcje międzynarodowe, redukcja zagranicznego finansowania).

Innym kluczowym kanałem oddziaływania spadku cen są pozycje zewnętrzne krajów. Zasadniczo, na skutek spadku cen ropy, pozycje zewnętrzne eksporterów pogarszają się, zaś importerów poprawiają. Szczególnie duże spadki nadwyżek płatniczych odnotowały kraje należące do GCC (Gulf Cooperation Council - Rady Współpracy Zatoki Perskiej), na czele z Arabią Saudyjska. Kraj ten jeszcze w roku 2013 odnotowywał nadwyżkę na rachunku obrotów bieżących sięgającą 18\% PKB, zaś w 2015 r. uległa ona głębokiej korekcie, przekształcając się $\mathrm{w}$ deficyt na rachunku obrotów bieżących sięgający $8 \%$ PKB. Istotne zawężenie nadwyżek płatniczych odnotowała też Norwegia, gdzie cena tamtejszej ropy spadła w ciagu półtora roku o $72 \%$. Nadwyżka płatnicza Norwegii uległa skurczeniu z $10 \%$ PKB w 2012 r. do niewiele ponad 4\% PKB w 2016 r., włączając w to zwrot z aktywów ulokowanych w Państwowych Funduszach Majątkowych. Wobec niepewności odnośnie przyszłego kształtowania cen ropy, w Norwegii rozpoczęła się dyskusja na temat potencjalnej rewizji reguły fiskalnej dotyczącej wpływów z eksportu ropy. Wyrażane są poglądy, że stosowana od $2001 \mathrm{r}$. reguła oparta na wydatkach (spending rule) jest bardziej 
racjonalną strategią niż reguła oparta na permanentnym dochodzie (permanent income rule) w warunkach spadku cen ropy. (Olsen, 2018).

W przypadku USA jednakże, ze względu na wysoki stopień niezależności energetycznej kraju, bilans handlowy jest w wysokim stopniu odizolowany od zmian cen energii. Szacuje się, że - uwzględniając obecną strukturę pozyskiwania zasobów energetycznych, wzrost cen ropy o 20 USD prowadzi do wzrostu deficytu na rachunku obrotów bieżących najwyżej o 0.1 \% PKB, a wpływ ten może być jeszcze mniejszy (IMF, 2018).

Jak wspomniano, ponieważ $\mathrm{w}$ okresie spadku cen ropy jednocześnie wzrastają dochody importerów, na skutek transferu dochodów dokonuje się globalna realokacja majątku. W 2015 r. MFW szacował, że 40\% spadek cen ropy powinien się przełożyć na transfer dochodów od eksporterów do importerów o około 1\% globalnego PKB. Zwracał także uwagę, że zjawisko utraty dochodów cechuje się wysokim stopniem koncentracji, jako że 5 krajów odpowiada za ponad połowę eksportu ropy, a 10 największych eksporterów za 75\% eksportu surowca. (Husain, 2015).

Ponadto, jak wskazuje MFW, taka redystrybucja środków między podmiotami o różnych preferencjach dotyczących oszczędności i konstruowania portfela inwestycyjnego może mieć reperkusje rynkowe, na przykład może powstać presja na podwyżkę globalnych długoterminowych realnych stóp procentowych. (IMF, 2015). Citibank wskazuje na możliwe negatywne efekty wynikające $\mathrm{z}$ niższych przepływów kapitału z krajów eksportujących ropę na globalne aktywa o stałym dochodzie. (Citibank, 2015).

Jak wskazuje jednak MFW, zarówno niższa globalna rola ropy w kreacji PKB, jak i rewolucja energetyczna w USA mogą oznaczać, że zmiany cen surowca będą miały słabnący efekt redystrybucji majątku w porównaniu do początku lat 2000. W szczególności, redystrybucja majątku z USA i innych eksporterów z krajów rozwiniętych w kierunku głównych eksporterów (Rosja, Arabia Saudyjska) może być znacznie słabsza. (IMF, 2018).

Bank Światowy dostrzega także inne globalne konsekwencje spadku cen - finansowe napięcia krajów emerging markets zaliczanych do tzw. dużych eksporterów ropy mogą wywołać efekt zarażania dla innych krajów zaliczanych do gospodarek wschodzących. Przykładem takiego oddziaływania było przełożenie napięć na rynkach finansowych Rosji na kraje Azji Środkowej. (World Bank, 2015).

Należy także zauważyć, że w przypadku krajów importerów, wyższe oszczędności publiczne i prywatne mogą podnosić aktywność gospodarczą poprzez niższe stopy procentowe, na skutek poprawy pozycji zewnętrznej i finansowej oraz niższej premii za ryzyko kraju.

Ostateczny wpływ niższych cen ropy na poszczególne kraje zależy od wielu czynników, w tym znaczenia surowca w ich eksporcie i imporcie, roli sektora w kreowaniu dochodów budżetowych, cyklu koniunkturalnego kraju, pola manewru dla polityki pieniężnej i fiskalnej.

\section{Implikacje spadku cen dla krajowych polityk makroekonomicznych}

Kształt polityki gospodarczej w reakcji na spadek cen ropy powinna zależeć od takich czynników jak: znaczenie szoków terms of trade (ich rozmiar i kierunek oddziaływania), uwarunkowania fiskalne i kształtowanie się pozycji zewnętrznej kraju, rodzaj reżimu 
kursowego, poziom inflacji, kształtowanie się cyklu koniunkturalnego w kraju oraz trwałość szoku. (Husain, 2015). Uwzględniając różnorodną naturę powyższych czynników, zarządzanie powstałym szokiem naftowym wymaga kombinacji polityk: pieniężnej, kursowej, fiskalnej i strukturalnej.

Dla importerów, spadająca inflacja może stwarzać pole dla akomodacyjnej polityki pieniężnej, która z kolei może wspierać wzrost gospodarczy. Jednakże, wobec słabego popytu globalnego i „bliskich zeru stóp procentowych” banku centralnego, a więc zjawisk, jakie występują przy obecnym szoku naftowym, polityka pieniężna musi stawić czoła naciskom deflacyjnym. Sytuacja ta, szczególnie odczuwalna w Europie, spowodowała konieczność kotwiczenia oczekiwań inflacyjnych poprzez luzowanie polityki pieniężnej lub stosowania jakościowego instrumentu polityki pieniężnej, jakim jest tzw. forward quidance.

W przypadku krajów eksporterów ropy o elastycznych reżimach kursowych, wyzwaniem dla banku centralnego jest znalezienie równowagi między takimi celami jak wspieranie wzrostu oraz utrzymanie stabilnej inflacji i zaufania inwestorów do waluty (World Bank, 2015). Analizując adekwatność reżimu kursowego w zarządzaniu szokiem cenowym, należy pamiętać, że gwałtownemu spadkowi cen ropy mogą towarzyszyć znaczne odpływy kapitału, utrata rezerw walutowych, gwałtowne deprecjacje kursu walutowego.

Wydaje się zasadnym, aby kraje o większej podatności na szok rozważyły deprecjację i/lub większą elastyczność kursową. Największy negatywny szok terms of trade uderzył kraje o stałych reżimach kursowych, stanowiąc tym samym dodatkową presję na rolę pozostałych polityk w procesach dostosowawczych. Nie oznacza to jednak, że dla wszystkich krajów eksporterów szoki cenowe na rynku ropy powinny oznaczać jednoznaczną rekomendację w postaci wzrostu elastyczności reżimu kursowego. Rekomendacja wzrostu elastyczności reżimu kursowego zależy od takich czynników jak: zdolność kraju do prowadzenia niezależnej polityki pieniężnej, wiarygodność przyjętego kursu centralnego, głębokość rynków finansowych, stopień dywersyfikacji struktur gospodarczych, elastyczność polityki fiskalnej. Jeśli udział sektorów nie opartych na ropie jest mały, a import towarów i usług duży, zmiany kursu odgrywają ograniczoną rolę w ułatwianiu niezbędnego dostosowania w popycie i równowadze zewnętrznej. (IMF, 2015).

Niższe ceny ropy oznaczają także istotne implikacje dla krajowych polityk fiskalnych. W przypadku krajów eksportujących surowiec, jeśli rząd nie ma odpowiednich buforów dla zapewnienia pokrycia wydatków, spadek dochodów budżetowych może uruchomić niezbędną konsolidację fiskalną. Wysokość istniejących buforów może determinować szybkość procesów dostosowawczych.

Dla krajów eksporterów charakteryzujących się dużym udziałem wydatków sztywnych w polityce fiskalnej, czynnikiem ułatwiającym proces dostosowawczy mogłaby okazać się elastyczność reżimu kursowego. Wydaje się, że kurs walutowy jest najbardziej naturalnym narzędziem procesów dostosowawczych. W trakcie ostatniego epizodu spadku cen, niektóre kraje doświadczyły deprecjacji kursu, zdewaluowały swoje waluty, lub pozwoliły na wzrost elastyczności kursu, podczas gdy inne pozostały przy kursie centralnym ustalonym do USD i wraz z nim pozwalały na aprecjację kursu (większość krajów GCC). W przypadku Rosji znamienne było wykorzystanie rezerw walutowych jako narzędzia stabilizującego. Duży drenaż rezerw i koszty interwencji przyczyniły się do tego, że w listopadzie 2014 r. Rosja przeszła na płynny reżim kursowy. Nie ma jednak konsensusu w badaniach empirycznych, że większa elastyczność kursu ułatwia 
dostosowania zewnętrzne. Eksporterzy ropy charakteryzują się takimi specyficznymi uwarunkowaniami, które obniżają efektywność kursu walutowego jako instrumentu dostosowawczego. A.Behar i in. podkreśla, że w następstwie deprecjacji może wystąpić skurczenie dochodu, ale niezdywersyfikowana gospodarka ogranicza zakres substytucji importu, droższy import jeszcze pogarsza więc bilans handlowy. Podobnie, (z kilkoma wyjątkami), producenci ropy są cenobiorcami, więc całkowite zyski z eksportu mogą nie być istotne. (Behar, 2016).

Z kolei MFW podkreśla, że elastyczny reżim kursowy pozwala częściowo uniknąć wpływu niższych cen ropy na dostosowania zewnętrzne i fiskalne, o ile nie ma istotnych niedopasowań walutowych wynikających, na przykład z wysokiego stopnia dolaryzacji. Z kolei kraje o stałych reżimach kursowych powinny, zdaniem MFW, zacieśnić polityki makroekonomiczne (szczególnie fiskalna), jeśli chcą utrzymać ten reżim kursowy.

W przypadku eksporterów, jest wiele czynników, które ograniczają wpływ kursu walutowego na wolumen handlu. Cena ropy jest ustanawiana w USD na rynkach międzynarodowych, a większość producentów doświadcza doskonale elastycznej krzywej popytu. W szczególności, w mniej zdywersyfikowanych gospodarkach, eksport nie pochodzący z ropy stanowi mały udział w koszyku eksportowym. Ponadto, wysoka zależność od importu oraz ograniczone możliwości substytucji, ograniczają odpowiedź wolumenów importu na ruchy cen relatywnych. (Behar, 2016).

Analizując zakres dostosowań fiskalnych podjętych w krajach eksporterach w reakcji na napięcia w równowadze zewnętrznej, można wyodrębnić kilka obszarów działań:

- cięcia wydatków (Zjednoczone Emiraty Arabskie, Arabia Saudyjska, Irak, Algieria). Wskazuje się, że kraje należące do GCC mają przestrzeń do cięcia wydatków publicznych, które bardzo się rozrosły w czasie boomu cenowego. Średnio kraje GCC wydają dwukrotnie tyle, co inne kraje zaliczane do tzw. emerging markets i rozwijające się na płace w sektorze publicznym, a prawie $50 \%$ więcej na inwestycje publiczne w stosunku do PKB.

- poszukiwania nowych źródeł dochodów: np. wzrost podatku dochodowego przedsiębiorstw (Oman), podatki od nowych kategorii towarów, np. alkohol, tytoń (Bahrajn). Kraje GCC planują wprowadzenie podatku VAT.

- zredukowanie ulg podatkowych (Iran).

- reformy cen energii - w krajach GCC wzrost opłat za wodę, elektryczność, paliwa (IMF, 2016).

Niektóre kraje (Algieria i Iran), oprócz dostosowań fiskalnych, zezwoliły swoim walutom na deprecjację, co podniosło dochody budżetowe w krajowej walucie.

W warunkach długookresowego spadku cen surowca, powstaje problem stabilizacji fiskalnej kraju (fiscal sustainability). Przy braku odpowiedniej konsolidacji fiskalnej, deficyty budżetowe będą musiały być pokrywane z zakumulowanych aktywów, poprzez emisję długu, lub pożyczanie z zagranicy. Niezbędne stanie się zatem znalezienie równowagi między wykorzystywaniem buforów finansowych, emisją długu (który co prawda pozwoli rozwinąc krajowe rynki kapitałowe, ale potencjalnie może wypchnąć prywatne inwestycje), a pożyczaniem środków z zagranicy.

MFW podkreśla także, że szybkie tempo procesów dostosowawczych w krajach eksportujących może być wzmacniane poprzez ponowne, gwałtowne oszacowanie ryzyka kredytowego i ryzyka kraju przez inwestorów, jednocześnie utrudnione przez wspomnianą ograniczoną dywersyfikację sektorową (IMF, 2015). Mimo, że kraje dotknięte negatywnym szokiem cenowym nie doświadczyły kryzysu w systemie bankowym, podkreśla się także, aby 
kraje szczególnie podatne na napięcia finansowe wzmocniły dodatkowo politykę makroostrożnościową.

Niższe ceny ropy stanowią dla eksporterów surowca okazję do przeprowadzenia reform strukturalnych, oraz podjęcia wysiłków w kierunku zdywersyfikowania produkcji. MFW zwraca uwagę na trudności w procesach dostosowawczych w przypadku słabej dywersyfikacji struktur eksportowych, co jest szczególnie widoczne w przypadku krajów należących do GCC. W przypadku tych krajów występują także inne ograniczenia dla polityk dostosowawczych: wysoki współczynnik przeniesienia zmian kursu walutowego na ceny w imporcie oraz ograniczona infrastruktura dla krajowej polityki pieniężnej, z uwagi na przyzwyczajenie tych krajów do wieloletniego stosowania kursu stałego w stosunku do USD. MFW rekomenduje tym krajom pozostanie przy reżimach kursów stałych, z naciskiem na rolę konsolidacji fiskalnej w procesach dostosowawczych. Wskazuje, że niski poziom długu publicznego umożliwia zwiększanie deficytów budżetowych, których finansowanie mogłoby jednocześnie - poprzez emisję papierów dłużnych - sprzyjać pogłębianiu krajowych rynków finansowych. (IMF, 2015).

Pozytywny przykład doświadczeń z dywersyfikacją struktur Meksyku i Malezji wskazuje, że następuje ona w warunkach malejących wpływów z eksportu ropy i polega zarówno na dywersyfikacji wertykalnej (w kierunku gazu, sektora petrochemicznego) oraz horyzontalnej (poza te sektory), z położeniem nacisku na wzrost zaawansowania technologicznego i wzrost konkurencyjności kraju (World Bank, 2015). MFW zwraca także uwagę, że niezbędne reformy w sektorze realnym i finansowym mogą wzmocnić rolę sektora prywatnego i tym samym przyspieszyć proces dywersyfikacji struktur eksportu (IMF, 2015).

Powyższe rozważania mają na celu zobrazowanie, że w dyskusji na temat optymalnej polityki gospodarczej dotyczącej krajów eksporterów borykających się ze spadkiem cen, występuje ciekawy nurt dotyczący tego, która polityka - fiskalna czy kursowa, powinna odgrywać aktywną rolę w procesach dostosowawczych. A.Behar wykazuje empirycznie, że - z uwagi na silne ograniczenia - pierwszoplanową rolę powinna odgrywać polityka fiskalna. W przypadku niezdywersyfikowanych eksporterów, kurs walutowy ma mały (lub żaden) wpływ na bilans obrotów bieżących, zaś polityka fiskalna istotny. W badaniach regresji, gdzie bilans handlowy jest zmienną zależną, wykazuje, że wartość waluty ma nieznacznie silniejszy wpływ na bilans handlowy niż na bilans obrotów bieżących, wydatki rządowe mają znacznie silniejszy wpływ na rachunek obrotów bieżących niż na rachunek handlowy. Rozważania te prowadzą zatem do wniosku, że zmiana kursu walutowego daje silniejszy impuls dostosowawczy w przypadku bardziej zdywersyfikowanych krajów. Autor zastanawia się jednocześnie nad kosztami i korzyściami obu instrumentów polityki dostosowawczej. Zwraca uwagę, że konsolidacja fiskalna może spowodować potencjalnie procykliczną redukcję w zagregowanym popycie. W przeciwieństwie, słabsza waluta może wspierać aktywność gospodarczą poprzez wzrost eksportu netto, ale jednocześnie może pogarszać bilanse, jeśli pasywa zagraniczne przewyższają zagraniczne aktywa. (Behar, 2016).

Dla krajów importujących, spadek cen ropy tworzy okazję do obcięcia kosztownych programów subsydiowania sektora energetycznego i skierowania tych funduszy na inne projekty infrastrukturalne i pro wzrostowe. Reformy takie zostały przeprowadzone min. w Egipcie, Indiach, Indonezji i Malezji w 2014 r., polegały głównie na usunięciu zniekształceń i nieefektywności związanych z subsydiami. Działania takie pozwalają poprawić sytuację fiskalną kraju i zwiększyć stopę oszczędności, inwestycje lub wydatki 
socjalne. Epizod spadku cen stanowi także dobrą okazję do wzmocnienia wiarygodności polityki pieniężnej.

Kraje należące do tzw. dużych importerów ropy (Brazylia, Indie, Indonezja, Turcja), skorzystały z niższych cen ropy, która przełożyła się na spadek inflacji i zredukowanie deficytu na rachunku obrotów bieżących. Niektórzy importerzy, na skutek efektów spillover, odczuli skutki spowolnienia gospodarczego w krajach eksporterach. Na przykład wspomniane już kraje Azji Środkowej odczuły negatywne konsekwencje recesji w Rosji, doświadczając obniżenia aktywności gospodarczej. (World Bank, 2015).

W przypadku krajów na niskim i średnim poziomie rozwoju, zarówno eksporterów, jak i importerów, podjęte reformy w sektorze energetycznym mogą mieć bardzo istotne korzyści dla rozwoju gospodarczego kraju.

\section{Podsumowanie}

W perspektywie długookresowej, zdaniem ekspertów, należy się spodziewać dalszego utrzymania się trendu zmienności cen ropy. W perspektywie najbliższych lat, swoista wojna cenowa między USA a krajami OPEC, prowadząca do nadpodaży surowca, powinna być wiodącym czynnikiem ograniczającym wzrost cen. Sprawia to, że eksporterzy ropy będą musieli znaleźć optymalny układ polityki gospodarczej, który pozwoli złagodzić negatywne konsekwencje spadku cen.

W trakcie ostatniego epizodu spadku cen ropy, cechą wspólną było pogorszenie pozycji zewnętrznych krajów eksporterów. Reakcja ze strony polityki gospodarczej była różna $\mathrm{w}$ poszczególnych krajach, co potwierdza tezę, że nie ma optymalnej policy mix w zarządzaniu negatywnym szokiem cenowym. Niektóre kraje wykorzystywały głównie aktywną politykę kursową, inne (np. Arabia Saudyjska) położyły nacisk na konsolidację fiskalna, dokonując cięć w wydatkach i przeprowadzając reformy strukturalne. Niezależnie od położenia punktu ciężkości między politykę kursową a fiskalną w procesach dostosowawczych, dalsze pogłębianie reform strukturalnych w krajach eksporterach jest kluczowe. Priorytetami reform są: poprawa środowiska biznesowego, redukcja luki w płacach sektora prywatnego i publicznego, prywatyzacja przedsiębiorstw państwowych.

Oprócz zaprezentowanych determinant cen, czynnikiem mogącym odegrać istotną rolę w kształtowaniu rynku surowca może być odejście od USD jako waluty rozliczania transakcji eksportowych na rynku ropy i oparcie ich w walutach innych krajów, na czele z Chinami. Proces wyłaniania się petrojuana, zapoczątkowany w 2014 r., wraz z akceptacją kilku krajów dla przeprowadzania transakcji w walucie chińskiej, może mieć istotne implikacje dla USA (deprecjacja USD, proces wzrostu stóp procentowych, recesja gospodarcza, wzrost kosztów obsługi długu publicznego), a także dla stabilności międzynarodowego systemu finansowego.

\section{Literatura}

Baffes, J., Kose, M., Ohnsorge, F., Stocker, M. (2015). The great plunge in oil prices: causes, consequences, and policy responses. Policy Research Note, World Bank Group, March.

Behar, A., Ritz, R. (2017). OPEC vs US shale: analyzing the shift to a market share strategy. Energy Economics, $63,185-198$. 
Behar, A., Fouejieu, A. (2016). External adjustment in oil exporters: the role of fiscal policy and the exchange rate, IMF Working Paper, no 16/107, June.

Bernanke, B. (2016). The relationship between stocks and oil prices. Ben Bernake's blog on Brookings, 19 February.

Baumeister, C., Kilian, L. (2015). Understanding the decline in the price of oil Since June 2014. CFS Working Paper no. 501

Fantazzini, D. (2016). The oil price crash in 2014/15: was there a (negative) financial bubble? Energy Policy, 96, 383-396.

Husain, A., Arezki, R., Breuer, P., Haksar, V. (2015). Global implications of lower oil prices. IMF Staff Discussion Note, July.

Khan, M. (2017). Falling oil prices: causes, consequences and policy implications. Journal of Petroleum Science and Engineering, 149, 409-427.

Jimebez-Rodriguez, R., Sanchez, M. (2005). Oil price shocks and real GCP growth: empirical evidence for some OECD countries. Applied Economics, 37(2), 201-228.

Mohaddes, K., Pesaran, M. (2017). Oil prices and the global economy: is it different this time around? Energy Economics, no 65, 315-325.

Obstfeld, M., Milesi-Ferretti, G., Arezki, R. (2016). Oil prices and the global economy: it's complicated. iMFdirect blog posted on March 24

Olsen, O. (2018). Does Norway save too much?, BIS Central banker's speeches, 22 March.

Tang, W., Wu, L., Zhang, Z. (2010). Oil price shock and their short- and long-term effects on the Chinese economy. Energy Policy, 32 sup. 1, S3-S14.

IMF. World Economic Outlook, April 2015.

IMF. External Sector Report, 2018.

IMF. MENAP oil-exporting countries: adjusting to cheaper oil, REO Update. Middle East and Central Asia Department, April 2016.

World Bank. Understanding the Plunge in oil prices: sources and implications, Global Economic Prospects, January 2015.

Do cytowania / For citation:

Bogołębska A. (2018). Spadek cen ropy naftowej w gospodarce światowej - główne przyczyny i konsekwencje. Analiza na przykładzie okresu 2014/2015. Problemy Rolnictwa Światowego, 18(4), 133-145; DOI: 10.22630/PRS.2018.18.4.104

Bogołębska A. (2018). The plunge of Oil Prices in the Global Economy - Main Determinants and Implications. Analysis on the Basis of the Period of 2014-2015 (in Polish). Problems of World Agriculture, 18(4), 133-145; DOI: 10.22630/PRS.2018.18.4.104 